\title{
Research on Application of Balanced Scorecard in the Government Performance Appraisal
}

\author{
Daokui Jiang, Zuankuo Liu \\ Business School, Shandong Normal University, Jinan, China \\ Email: jdk240504@163.com
}

Received April 2014

\begin{abstract}
The Balanced Scorecard (BSC), a strategic performance management tool, is well received and applied by many world organizations; however government organizations have not really implemented it. Government management issue has no organic relationship with system innovation, institutional reform and transformation of functions. There is a lack of scientific and reasonable performance appraisal indicators for government reform, let alone the improvement of the government management level. The study was carried out to construct the Chinese government performance appraisal system using the BSC method, which mainly in the aspect of financial perspective, customer perspective, internal process perspective and learning and growth perspective. The application and implementation of the BSC can be an important measure of government management innovation, and plays an important role in the process of function transition and administrative system reform.
\end{abstract}

\section{Keywords}

Balanced Scorecard, Performance Management, Appraisal

\section{Introduction}

As a new management tool, the BSC has received wide attention from both practitioners and academics in Western nations since it was developed by Kaplan and Norton. In 2008, a survey showed that $53 \%$ of respondents reported that firms had implemented the BSC in varying degrees, ranging from minimum-standard to fully developed [1]. Not long after it was introduced, the BSC came into wide usage in many organizations, including $60 \%$ of Fortune 1000 firms. At the same time, it became the ongoing dominant topic related to performance measurement in academic journals, and Kaplan and Norton's publication has been one of the most cited articles. However, the reported high failure rate of the BSC along with the mixed research findings about its effectiveness have resulted in questions about the validity of some assumptions underpinning the BSC [2] [3].

Kaplan \& Norton noted that the BSC is not just a performance measurement system but also a strategic control system that is able to handle the problem of strategy implementation [4]. The BSC for non-profit organiza- 
tions and governmental agencies was launched with the customer perspective on top, replacing the financial perspective. Performance appraisal as a tool for assessing and improving government performance, has been widespread concern by the government and scholars all over the world, and become the modern public management research topic. Under the Chinese market economy system, the main function of the government is to provide public services according to the social development and the public needs.

\section{BSC and Government Performance Management}

\subsection{Balanced Scorecard}

The Balanced Scorecard developed by Kaplan and Norton comprises four perspectives, namely finance, customer relations, internal business process and lastly, learning and growth. It reflects a balance between shortand long-term objectives, financial and non-financial measures, lagging and leading indicators, and external and internal measures. It emphasizes linking and aligning multiple measures to strategic objectives, and conceptualizing the strategic alignment between business goals and specific tactics.

To implement a BSC framework, a manager must establish the strengths of all relationships and determine their relative importance. The purpose is integrating all former performance evaluation systems into a balanced method [5]. The method is based on the definition of a set of performance indicators under four perspectives, creating a scorecard which enables the managers to immediately gain an insight into the company's performance with a balanced view. Norlaila examined the use of the BSC to achieve desired transformation, the role of management accountants and the critical factors for the successful implementation of the BSC model in a selected Malaysian government-linked company [6].

Since the late 1980s, many scholars expressed concern about traditional performance measures that focused solely on financial metrics [7] [8]. It has been widely adopted as a performance evaluation framework. The BSC was employed by more than $60 \%$ of the fortune 1000 companies. As organizations endeavor for value creation and future growth, conventional unidimensional financial measures increasingly become inadequate and irrelevant.

\subsection{Government Performance Management}

The government performance evaluation can be traced back to American municipal public sector performance evaluation in the early of 20th Century [9]. To the 1980s, the western countries generally carried out new public management, and led to the formation of the emphasis on public service in customer orientation and results orientation. Since the 1990s, the government performance evaluation, not only focus on the economy, efficiency and effectiveness, but also focus on the service quality and citizen satisfaction, so performance evaluation get more institutionalized and standard.

After the reform and opening up, Chinese government performance evaluation have been achieved a lot in theory and practice. But there are still some problems, mainly in: the lack of guidance of government performance evaluation of the mature theory system; the lack of corresponding laws, and regulations; evaluation system itself is not perfect; the application of assessment result and the evaluation index is not scientific; the lack of supervision mechanism; and the required data, information infrastructure is weak [10]. Government performance evaluation is to assess the performance of government, in the social and economic management activities of the efficiency and the effect, and it is to the government in the exercise of its political, economic, social, administrative functions, assessment will process management ability. Because of involving a wide range, many factors cannot be measured directly, so the evaluation will inevitably appear in both objective and subjective indexes.

\section{Appraisal System of Government Performance}

As mentioned above, the BSC model views the organizational performance from four perspectives: financial, customer, learning and growth and internal processes.

\subsection{Financial Perspective Index}

The financial perspective plays a dual role of defining the financial performance of an organization with the im- 
plementation and execution of the strategic plans, as well as evaluating the organization's profitability using tools. The financial indicators that are analyzed differ from company to company. The most common mistake that most of the organizations do is to focus too much on the financial indicators ignoring totally or partially the other perspectives.

Due to the administrative department is pure public product, its interest to social distribution, to evaluate the expenditure performance through effective use of rationality and funds expenditure. The administrative expenditure on non productive social spending, the funds once used, it will cause the social consumption of material goods. If the government administrative costs too much, the government had to compression for infrastructure investment, economy, education, health and other aspects of the expenditure, thus affecting the entire public goods allocation efficiency. So the financial index should be focus on administrative costs and administrative expenses of the effectiveness and rationality. Select the quantity and quality of public service, public management goals, the policy level and effect, beneficial result of public management stands for financial status.

\subsection{Customer Perspective Index}

All four Balanced Scorecard's perspectives have the same importance, but the customers are the main reason of existence for any organization. They think that employees from many organizations do not know what customers need and in which extent their activity affects them. The customer perspective is a leading indicator that helps the organization evaluates customer satisfaction with its brand or services. This is necessary to ensure strong customer loyalty, besides attracting new customers.

The public sector provides public services, taking public interest as value orientation, so both administrative performance evaluation standards or activities must reflect the social justice and reasonable. Strengthening the service consciousness and "cost-benefit" concept, the government managers should aware the importance of citizen participation in assessment and performance evaluation of democracy, whose purpose and the endpoint is the power back to the public. The main concerns of the customers can be classified in three categories: service the public, accept the supervision, and cooperate with the public.

\subsection{Learning \& Growth Perspective Index}

Organizations must learn that employees are very important not only for their specific tasks, but also for their creativity and ability of developing new ideas. The need for employee knowledge, skills and abilities can be very important especially when new technologies and processes come to the market. The learning and growth perspective identifies the areas of excellence or competencies that an organization has to achieve value creation.

Learning and growth index was used by various kinds of macro and micro organization's management, internal and external environment. Enterprises use the feedback of learning and growth index to formulate long-term development planning and target, optimize resources integration, to meet the external competition and challenge to get sustainable development. With the social transformation and modernization ahead, the government will face a complex, pluralistic environment; the government needs clear objectives, resources integration and strategic planning of the practical application. The main concerns of learning and growth can be classified in four categories: the system construction, Party organization building, administrative style, and clean and honest administration construction.

\subsection{Internal Processes Perspective Index}

This perspective focuses on all activities and processes that are critical for the organization in providing the expected value for the customers. The main condition in obtaining the desired results from process improvements is to assess the organization performance, to identify the possible problems that affect the quality of the products. The internal business process focuses on the internal operations of the organization, enabling managers to evaluate their businesses efficiently, what makes the BSC unique, compared to other traditional performance measures?

The core of deepening reform of the administrative system is the transformation of government functions, and establishment of internal processes plays the transformation of government functions. Effectiveness and administrative work of business processes fully reflects the government service, to solve the problem of government function vacancy, offside and dislocation of government functions, the key to social management and public 
service, safeguard the legitimate rights and interests of the masses, accelerate the process of function change. Here we choose the job responsibilities, administration according to law, Government decrees fully implement.

\section{Test of the Appraisal System}

This paper adopted a web-based e-mail survey design to collect data to study the appraisal system validate. The questionnaire mainly includes two aspects: the demographic variables, including gender, age, educational degree, occupation, and income; appraisal index, including aspects of performance. All of the performance index variables were based on a five-point Likert-5 scale ranging from "strongly disagree" to "strongly agree".

The object of study is engaged in industrial and commercial management in the enterprise's staff, government workers, and scientific researchers. A total of 500 questionnaires were mailed. Follow-up letters, e-mails and phone calls were done after 4 weeks. Of the 352 questionnaires returned, 46 responses were incomplete. The remaining 306 valid and complete questionnaires were used for the quantitative analysis. The sample distribution, gender, male $46.7 \%$, female $53.3 \%$; age distribution, under 20 years of age accounted for $0.3 \%$, $21-30$ years of age accounted for $24.2 \%$, 31 - 40 years of age accounted for $40.2 \%$, 41 years old accounted for $35.3 \%$; the educational degree, high school and below accounted for $32.7 \%$, college education accounted for $63.7 \%$, master degree and above accounted for 3.6\%; the income status, 2000 and below counts $6.2 \%, 2000-3000$ counts $23.9 \%$, 3000 - 5000 counts $38.2 \%$, and 5000 and above counts $31.7 \%$.

\subsection{Reliability and Construct Validity}

This paper use Cronbach's $\alpha$ and CICT coefficient to test the internal consistency, using principal component analysis to examine the construct validity. The results showed that, the measured CITC value is higher than 0.8 , the overall Cronbach's $\alpha$ is 0.954 . The conclusion is that, internal consistency appraisal system is high. The principal component factor was used to analysis the Construct validity. Extract factors that that more than 1 feature value. Varimax rotation was used to find common factor variance maximization. Principal component analysis results of KMO value is 0.954 . Bartlett test is 0.003 . Four common factors are extracted, and the cumulative variance is $68.83 \%$.

The first factor corresponds financial perspective one, including 4 items; the second factor corresponds customer perspective, including 3 items; the third factor corresponds learning \& growth perspective, including 4 items; the fourth factor corresponds internal processes perspective, including 3 items (Table 1).

\subsection{Predictive Validity}

This study investigated the relationship between performance index and work outcomes by regression analysis. Four dimensions and the specific content of performance system are selected as independent variables and job income as the dependent variables. Gender, age, educational background is the control variables.

After descriptive statistics of variables and the correlation coefficient matrix, there is a negative significant relationship between gender and age, in accordance with common sense. There is a positive correlation between age and income levels, while there is a significant negative relationship between age and education level. There is no significant relation between dimensions of performance and gender. The work performance has no direct relation with gender. There is a positive correlation between education level and income, and as the educational degree increases, the income will increase (Table 2).

There is a positive relationship among four dimensions of performance, that is, the four dimensions of work performance are interacted. While, from the correlation coefficient matrix, we can find that, there is no direct relationship between with performance and individual income. The conclusion is in accordance with some research results [1]. From this point of view, we can say, the high work performance cannot direct lead to high income.

\section{Conclusion and Discussion}

The government performance appraisal system is introduced to the process of Chinese administrative system reform, which will be very meaningful for promoting the reform of local administrative system. This study builds the government performance appraisal system based on the Balanced Scorecard. However, to ensure the local government sustainable performance evaluation activities, it is necessary to reform the operational me- 
Table 1. Government performance appraisal index system.

\begin{tabular}{|c|c|c|c|c|c|}
\hline \multirow{2}{*}{ Dimensions } & \multirow{2}{*}{ Content } & \multicolumn{4}{|c|}{ Rotated Component Matrix } \\
\hline & & 1 & 2 & 3 & 4 \\
\hline \multirow{4}{*}{ Financial Perspective } & quantity and quality of public service & 0.655 & 0.403 & -0.061 & -0.100 \\
\hline & public management goals & 0.757 & 0.429 & -0.165 & -0.068 \\
\hline & the policy level and effect & 0.761 & 0.218 & -0.057 & 0.083 \\
\hline & beneficial result of public management & 0.725 & 0.171 & -0.072 & 0.208 \\
\hline \multirow{3}{*}{ Customer Perspective } & service the public & 0.063 & 0.772 & 0.013 & 0.192 \\
\hline & accept the supervision & -0.010 & 0.801 & 0.152 & 0.124 \\
\hline & cooperate with the public & 0.053 & 0.781 & 0.175 & 0.189 \\
\hline \multirow{4}{*}{$\begin{array}{l}\text { Learning \& Growth } \\
\text { Perspective }\end{array}$} & the system construction & 0.014 & 0.252 & 0.763 & 0.031 \\
\hline & party organization building & 0.014 & 0.046 & 0.754 & -0.236 \\
\hline & administrative style & -0.029 & 0.132 & 0.834 & -0.188 \\
\hline & clean and honest administration construction & -0.163 & 0.065 & 0.825 & -0.140 \\
\hline \multirow{3}{*}{$\begin{array}{l}\text { Internal Processes } \\
\text { Perspective }\end{array}$} & job responsibilities & -0.133 & 0.055 & -0.010 & 0.840 \\
\hline & administration according to law & -0.319 & -0.227 & 0.032 & 0.826 \\
\hline & government decrees fully implement & -0.259 & -0.076 & 0.003 & 0.785 \\
\hline
\end{tabular}

Extraction Method: Maximum Likelihood.

Table 2. Descriptive statistical and correlation coefficient matrix.

\begin{tabular}{|c|c|c|c|c|c|c|c|c|c|}
\hline & Mean & S.D & 1 & 2 & 3 & 4 & 5 & 6 & 7 \\
\hline 1 Gender & 1.53 & 0.50 & 1 & & & & & & \\
\hline 2 Age & 3.11 & 0.77 & $-0.12^{*}$ & 1 & & & & & \\
\hline 3 Education & 1.71 & 0.53 & -0.02 & $-0.20^{* *}$ & 1 & & & & \\
\hline 4 Income & 2.95 & 0.90 & $-0.13^{*}$ & $0.17^{* *}$ & $0.33^{* *}$ & 1 & & & \\
\hline 5 Financial & 3.40 & 0.72 & 0.01 & -0.01 & 0.05 & 0.06 & 1 & & \\
\hline 6 Customer & 3.24 & 0.84 & 0.01 & -0.06 & 0.11 & 0.08 & $0.64^{* *}$ & 1 & \\
\hline 7 Growth & 3.33 & 0.86 & 0.02 & $-0.12^{*}$ & 0.10 & 0.02 & $0.67^{* *}$ & $0.68^{* *}$ & 1 \\
\hline 8 Process & 3.25 & 0.83 & -0.01 & -0.08 & 0.05 & 0.02 & $0.60^{* *}$ & $0.68^{* *}$ & $0.71^{* *}$ \\
\hline
\end{tabular}

***. Correlation is significant at the 0.01 level (2-tailed); ${ }^{*}$. Correlation is significant at the 0.05 level (2-tailed).

chanism, through the introduction of market competition mechanism, so as to establish the basis for the effective operation of the government performance evaluation system. The government function indexes can be divided into economic regulation, market supervision, social management, public service and the management of state-owned assets. So in the development of local government performance evaluation index system, the government should focus on their special indexes. Performance appraisal implementation related to the work of fairness, impartiality, and openness. So who act the executive of government performance evaluation is an important issue, which must be paid more attention to.

\section{Acknowledgements}

We thank the editors and anonymous reviewers for constructive comments. Financial supported by Shandong 
Province Statistical Department (No. KT13144), Shandong province regulations project (optimization of financial industry, regional development and collaborative management innovation center) are gratefully acknowledged.

\section{References}

[1] Zeng, K.S. and Luo, X.H. (2013) The Balanced Scorecard in China: Does It Work? Business Horizons, 56, 611-620. http://dx.doi.org/10.1016/j.bushor.2013.06.001

[2] Ittner, C.D. and Larcker, D.F. (2003) Coming Up Short on Non-financial Performance Measurement. Harvard Business Review, 81(11), 88-95.

[3] Nørreklit, H. (2000) The Balance on the Balanced Scorecard: A Critical Analysis of Some of Its Assumptions. Management Accounting Research, 11, 65-88. http://dx.doi.org/10.1006/mare.1999.0121

[4] Kaplan, R.S. and Norton, D.P. (1996) Using the Balanced Score-Card as a Strategic Management System. Harvard Business Review, 74, 75-85. http://doc.mbalib.com/view/9eaabef54c683362d5e2eae3505b9a47.html

[5] Guimarães, B., Simões, P. and Marques, R.C. (2010) Does Performance Evaluation Help Public Managers? A Balanced Scorecard Approach in Urban Waste Services. Journal of Environmental Management, 91, 2632-2638. http://dx.doi.org/10.1016/j.jenvman.2010.07.039

[6] Zin, N.M., Sulaiman, S., Ramli, A. and Nawawi, A. (2013) Performance Measurement and Balanced Scorecard Implementation: Case evidence of a Government-linked Company. Procedia Economics and Finance, 7, 197-204.

[7] Hoque, Z. (2014) 20 Years of Studies on the Balanced Scorecard: Trends, Accomplishments, Gaps and Opportunities for Future Research. The British Accounting Review, 46, 33-59. http://dx.doi.org/10.1016/j.bar.2013.10.003

[8] Tjader, Y., May, J.H., Shang, J., Vargas, L.G. and Gao, N. (2014) Firm-Level Outsourcing Decision Making: A Balanced Scorecard-Based Analytic Network Process Model. International Journal of Production Economics, 147, 614623. http://dx.doi.org/10.1016/j.ijpe.2013.04.017

[9] Harkin, J.M. (1982) Effectiveness Budgeting: The Limits of Budget Reform. Policy Studies Review, 2, 112-126. http://dx.doi.org/10.1111/j.1541-1338.1982.tb00630.x

[10] Lu, H.Y. (2009) Local Government Performance Evaluation: Experience, Plight and the Way Out. Chinese Public Administration, 6, 31-33. http://www.cnki.com.cn/Article/CJFDTotal-ZXGL200906011.htm 